\title{
ЛІНГВІСТИЧНА ІНТЕРПРЕТАЦІЯ ТЕМПОРАЛЬНИХ МЕТАЛОГІЧНИХ ОБРАЗІВ В УКРАЇНСЬКОМУ ІДІОПИСЫМІ (НА ПРИКЛАДІ ТВОРЧОСТІ ІРИНИ ЖИЛЕНКО)
}

Мішеніна Т. М. Лінгвістична інтерпретація темпоральних металогічних образів в українському ідіописьмі (на прикладі творчості Ірини Жиленко).

У публікації розкрито особливості мовно-стилістичних засобів, що дають змогу виявити найприкметніші характеристики ідіостилю письменника та специфіку його світосприйняття на прикладі астральної моделі світу в поезії Ірини Жиленко, мовним вираженням якої є темпоральні відповідники - металогічні образи пір року.

В українській мовній картині світу циклічне розуміння часу переважає над лінійним (це зумовлено тим, що люди почали сприймати час більш конкретно та пов'язувати його плин зі своєю трудовою діяльністю, розмежовуючи абстрактне поняття «час» на більш конкретні відрізки (цикли), пов’язані із рухом астронімів у космічному просторі i, відповідно, змінами в природі). Пори року допомагають осмислити вічний перебіг часопростору Всесвіту, віднайти смисл життєвої путі людини, досягти гармонії з навколишнім світом, оскільки перманентною ознакою всесвіту є взаєморозуміння, невпинний діалог.

Ключові слова: астронімна картина світу, категорія темпоральності, пора року, автологічний образ, металогічний образ, лінгвокультурема.

Мишенина Т. М. Лингвистическая интерпретация темпоральных металогических образов в украинском идиописьме (на примере творчества Ирины Жиленко).

В публикации раскрыты особенности культурно-стилистических средств, позволяющих выявить наиболее замечательны характеристики идиостиля писателя и специфику его мировосприятия на примере астральной модели мира в поэзии Ирины Жиленко, языковым выражением которой является темпоральные соответствия металогичних образы времен года. 
В украинской языковой картине мира циклическое понимание времени преобладает над линейным (это обусловлено тем, что люди стали воспринимать время более конкретно и связывать его течение со своей трудовой деятельностью, разграничивая абстрактное понятие «время» на более конкретные отрезки (циклы), связанные с движением астронимов в космическом пространстве и, соответственно, изменениями в природе). Времена года помогают осмыслить вечный ход времени и пространства Вселенной, найти смысл жизненной пути человека, достичь гармонии с окружающим миром, поскольку перманентной признаком вселенной является взаимопонимание, непрерывный диалог.

Ключевые слова: астронимная картина мира, категория темпоральности, время года, автологический образ, металогический образ, лингвокультурема.

Mishenina T. M. Linguistic Interpretation of temporal metalogical patterns in Ukrainian idiostyle (based on the works of Iryna Zhylenko).

The publication deals with linguistically and stylistic tools to identify the most notable characteristics of the specific idiostyle of writer and his outlook on the example of the astral world model Irina Zhylenko' poetry, means of language explication, which are temporal counterparts - metalogical images of seasons.

In the Ukrainian language world cyclical understanding of time prevails over the line (this is because people began to understand it more specifically and to bind its course with their employment, distinguishing between the abstract concept of "time" at a specific intervals (cycles) associated with the movement astronim's in outer space and, consequently, changes in nature).Poetry Irene Zhylenko certifies functioning of autologous and metalogical images seasons. Metalogical temporal correspondences was constituted on folk images simultaneously observe copyright rethinking. Poetry of Irene Zhylenko certifies functioning of autologous and metalogical images seasons. Metalogical temporal correspondences were constituted on folk images simultaneously observed copyright rethinking.

Spring refers to the state of mind. The vitality of the human author identifies with the concept "spring", that achieving high goals, bright dreams, beautiful wishes and sincere feelings. Thesis there is determined such associative chains spring - light - silver gold - the morning of the fire - wind - Flowering branches - sun - the bride thunder light - people. Functional synestesy is the image of man-spring, when lyrical heroine identifies its state on the state of nature. Summer appears as a correlate of mental state - of joy. The image of fall is compared with a time when the soul dreams. Fluidity of this world, that really is truly a living soul - the soul bloom. The opinion by the author embodies the contrast in verses keywords life / death; neglect / flowering; earth / divinity; soul / earth / God. The prospect of further research is to study the functionality of linguistic units to describe correlates of earth model of the world.

Key words: astronimical picture of the world, the category of temporality, time of year, autologous images, metalogical image, linguaculture.

У сучасній філологічній думці внутрішня форма художнього твору витлумачується як рівень, який убирає в себе сукупність засобів предметного зображення у творі, на відміну від рівня словесного 
зображення (сукупності словесних прийомів) та структурноорганізуючого рівня - композиції; у художньому творі такий рівень форми постає у вигляді динамічної картини зображуваних автологічних і металогічних художніх образів.

Дослідник Л. Тимофєєв [7, c. 60] загальноприйнятому в сучасному літературознавстві «образ - це конкретна i водночас узагальнена картина людського життя, що створена за допомогою вимислу й має естетичне значення» протиставляє широковживаному, але термінологічно не конкретизованому визначенню образу як узагальненого відображення дійсності у формі одиничного, індивідуального. Зокрема, в основі художнього образу як специфічної форми відображення дійсності лежить первинний, або так званий чуттєвий образ, позначений емоційністю (настановою на підкресленоемоційний характер вираження думки); узагальненістю свого змісту. Оскільки суттєвою відмінною ознакою літературно-художнього образу $€$ те, що він відтворює динамічний образ дійсності, який розгортається в системі своєрідних взаємовідображень форм зображення, що конкретизують його, на окрему увагу заслуговують художні кореляти картин природи як реалізації категорії темпоральності загалом, пір року у межах астронімної картини в межах мовної картини світу - зокрема.

Питання мовної картини світу розглядалося багатьма вітчизняними і зарубіжними науковцями: Ю. Апресян, Н. Арутюнова, Л. Вайсгербер, А. Вежбицька, О. Голубовська, Ю. Караулов, В. Маслова, Н. Сукаленко, Ю.Степанов, І. Штерн; мовну реалізацію категорії темпоральності розглядали О. Задорожна, Ю. Дем'янова, 3. Дударева.

Актуальність публікації зумовлена недостатнім вивченням поняття астральної моделі, яка $\epsilon$ перспективною темою задля подальших лінгвістичних досліджень, оскільки особливості іiі створення, використані мовно-стилістичні засоби дозволяють виявити найприкметніші характеристики ідіостилю письменника та специфіку його світосприйняття. Чітко окресленою і змістовно важливою $\epsilon$ 
астральна модель світу в поезії Ірини Жиленко, мовним вираженням якої є темпоральні відповідники - металогічні образи пір року.

Мета публікації - розкрити структурно-семантичні особливості темпоральних металогічних образів як стилетвірних чинників ідіостилю.

Час - це всезагальна форма буття, що виражає протяжність i послідовність зміни усіх матеріальних систем і процесів у світі. Абстрактність і багатогранність часу як форми існування матерії зумовлює розбіжності в його трактуванні. До кількісних характеристик часової стихії відносять подільність, нескінченність, одномірність. До якісних - незворотність, впорядкованість, сталість / мінливість, безперервність, ритмічність, темп, наявність трьох часових сфер - минулого, теперішнього і майбутнього [3, с. 113]. Часова модальність - це категорія, яка виражає певні часові відносини на відповідному рівні організації матерії. Якщо розглядати духовний план людини, то можна говорити про художній час, історичний час, час індивідуального людського буття тощо [6, с. 178].

Мовну фіксацію часових координат лінгвісти насамперед пов'язують iз граматичними, лексичними i функціональностилістичними засобами, що утворюють систему мовної темпоральності, яка притаманна всім рівням мовної системи [1, с. 89].

Попри відсутність єдності поглядів на тлумачення категорії часу диференціація абсолютного (який не має стосунку до подій, він існує і триває рівномірно сам по собі), лінійного (абстрактні поняття часових відношень) й емпіричного (циклічного) часів ніколи і ні в кого не викликала принципових заперечень.

Циклічна модель часу пояснює природничий аспект цієї категорії, а лінійна модель відображає історичний (суспільний) час. У повсякденному житті людина вимірює час астрономічними циклами. Час саме в цьому значенні є визначальним у нашому дослідженні, оскільки астрономічний час разом із небесними тілами, рухом яких він зумовлений, становлять астральну модель світу. 
В українській мовній картині світу циклічне розуміння часу переважає над лінійним. Така перевага зумовлена тим, що люди почали сприймати час більш конкретно та пов'язувати його плин зі своєю трудовою діяльністю, розмежовуючи абстрактне поняття «час» на більш конкретні відрізки (цикли), пов'язані із рухом астронімів у космічному просторі і, відповідно, змінами в природі. Тому є апріорним твердження, що астрономічний час $\epsilon$ невід’ємним складником астральної моделі світу, який визначає саме існування життя на землі.

Лінгвальна реалізація категорії темпоральності в поезії Ірини Жиленко відбувається через реалізацію темпоральних значень, носіями яких у контексті є окремі лексичні одиниці на позначення пори року. Диференційною ознакою ідентифікації вербалізатора концепту «час» уважаємо наявність часової семи. Оскільки узуальні темпоральні значення кодифіковані в сучасних словниках тлумачного типу, реалізація цих значень у прозовому контексті будуть зіставлені 3 їхнім лексикографічним описом.

Художні метологічні образи пори року $\epsilon$ самозначущими художніми образами, виступають як засіб узагальнення, мета якого полягає в організації естетичного впливу через свого роду «ефект упізнавання». Самозначущий образ - це образ, який фіксує типові, характерні, найбільш суттєві (в естетичному відношенні) аспекти зображуваного. Типовий образ об'єднує в собі ознаки, спільні для більшої кількості однорідних предметів; вибрані для зображення такого предмета спільні риси й ознаки називаються типовими або характерними. Типово можуть бути зображені природні явища, характерні для певної пори року. Металогічний тип художнього образу пори року відтворює чуттєвий образ, який є формою вияву такої ідеї, яка, узагальнюючи зміст одиничного предмета, виходить за його межі і вказує на якийсь інший, якісно відмінний від нього предмет. Чуттєвий образ та ідея належать до різного кола явищ. До групи металогічних образів відносять символ, алегорію та підтекст. Найяскравішим виявом металогічного образу є символ (а) традиційна символіка, усталені 
образи-символи, які органічно закріпилися за певними, в основному природними об'єктами, в суттєвих ознаках яких констатуються певні аналогії з ціннісними виявами людського життя (життя / шлях; пори року / вік людини; хмари / нещастя; ворона / смерть; райдуга / предтеча щзастя); б) зображуване набуває символічних ознак безпосередньо в процесі самого зображення, $є$ індивідуально-авторськими).

Матеріальними носіями символіки пір року в художньому творі є складники: метафори, пейзажі, художні деталі. Найбільш уживаними в системі образів пір року є образи ліричного героя (образ автора) й пейзаж.

Пейзажем називається образ природного оточення персонажів та їхніх дій, опис картин природи в художньому творі, який має певне значення в його загальній змістовій організації. Найважливіша функція пейзажу полягає в тому, що він виступає у творі як додатковий опосередкований засіб характеристики окреслюваних у ньому героїв, персонажів. Здебільшого відношення пейзаж - людина в художньому творі будується на принципах так званого психологічного паралелізму - контрастного протиставлення, або зіставлення картин природи 3 душевним станом, емоційним людини.

Схарактеризуємо структурно-семантичні особливості темпоральних металогічних образів як стилетвірниого чинника ідіостилю (на прикладі творчості Ірини Жиленко).

Образ весни - пора року між зимою й літом, яка характеризується подовженням дня, потеплінням, появою перелітних птахів, розквітом рослин тощо [2, с. 124]. В українській лінгвокультурі весна - торжество на честь богині життя Лади та іiі доньки - богині кохання Лелі; образ пори року у вигляді гарної молодої дівчини з вінком квітів на голові; дівчину-весну закликають піснями-веснянками [5, с. 80]. У світоглядній картині світу Ірини Жиленко весна співвідноситься зі станом душі. Життєвість людини авторка ототожнює 3 поняттям весняності, тобто досягнення високих цілей, світлих мрій, красивих бажань, щирих відчуттів: I плаття моє білосніжне розквітло - / Біжу по воді 
нареченою світла. / На мить (чи на вічність?) розмаяло втому / Квітучою гілкою, сонием і громом. / Я - світло, я-вітер, я - біг по піску, / Я - дріж золотий, щзо поймає ріку. / Я - та, щзо на ранок збиває вогонь ... (5, с. 44-45). У наведених строфах спостерігаємо ототожнювально-референтні конструкції, аналіз яких дозволяє виокремити такі асоціативні ланцюжки: весна - світло - дріж золотий - ранок із вогню - вітер - квітуча гілка - сонце - грім наречена світла людина. Спостерігаємо діалектичний взаємозв'язок між весною і поступовим перетворенням людини на весну через вияв станів, характерних для весни. Рефлективність усвідомлення стану людиною здійснюється через категорії: «швидкість», «легкість», «світло», «вогонь», «прагнення», «щирість», «політ» тощо.

Оригінальним авторським рішенням намагання метафорично відтворити весняний стан душі через опис конструктивних емоцій: О захват! О сміх екстатичний! О дзвін! / О трави - обличчям в заграви колін! / О крові моєї багряний літак, / Котрому довіку літать i літать... (5, с. 45).

Окремо виносимо рядки: На мить (чи на вічність?) розмаяло втому / Квітучою гілкою, сонщем $і$ громом. На нашу думку, їх слід інтерпретувати як усвідомлення авторкою континууму стану весняності, яка виявляється пульсації, новому що миттєвому захопленні навколишнім світом, динамізмом у пізнанні світу, що асоціюється із пробудженням.

Кульмінація внутрішнього болю головної героїні полягає в ототожненні духовного спустошення зі смертю. Смерть в усвідомленні людини асоціюється із регресом, перериванням зростання, певних зрушень, поступів. Отже, не весняна людина є по суті неживою людиною. Оригінальним, на нашу думку, у наведених строфах є вирішення подати образ весни через образ свічки, яка поступово згасає. Докладність опису станів згасаючої свічки і сліз представляють образ поступової, але неповоротної втрати людиною свого живого єства. 
Авторка своєрідно сприймає весняну пору року крізь призму відчуття часових періодів ранку, дня, вечора весняної пори: Мені приснились: я доросла стала. / Така собі звичай і сумна... / А у вікні нічна весна світала. / I зеленіла, й пошепки сміялась, / Самими тільки віями сміялась ... (5, с. 212). У поетичному контексті наводиться діалог iз персоніфікованою Весною, яка висловлює своє бачення стану ліричної героїні. Цікавим є зіставлення самоусвідомлення і сприйняття Весною ліричної героїні: «Яка смішна!» - вона мені сказала. / «Яка дурна!» - крізь сміх вона сказала. / ... Тишина. / Так зелено, / Так солодко не спиться! / 3-за моря засміялася весна... (5, с. 213).

Виокремлюємо синестезійний образ людини-весни, коли лірична героїня ототожнює свій стан зі станом природи, зокрема наводимо поетичний уривок, що відтворює картину квітучого весняного саду: Я вже збагнула: він мене кохав, / ией сад... / Шепоче гілля: «3 нами довікуй!» / I зацвіла я пошепки. I впала. / Як з берега в малинову ріку, / У мене білі яблуні вступають. / Волочать довгі віти по мені. / I заплітають, і бурхливо пестять / Моє лице в гарячім полині, / I тіло, упокорене й безчесне. / А яблунька з рожевими димами / Між білих рук шепоче: «Не журися. / Нас тут багато - молодих сестриць, / Вставай і зацвітай собі між нами..» (5, с. 37).

Медитативне самоусвідомлення відтворюєтся в поетичному контексті на рівні образів: весна - яблуня з рожевими димами сестриці - квітуча Людина-весна. Родинне відчуття навколишнього світу перетворюється на відчуття весняного піднесення.

Літо - найтепліша пора року між весною та осінню [2, с. 623]. Українська лінгвокультура репрезентує літо крізь призму сподівання на врожай (Літо родить, а не поле; Літо раз родить; Бджоли раді иявіту, люди-літу); за християнськими уявленням літо називали також Святим Петром (найбільше цієї пори свято 12 липня) [4, с. 80]. В усвідомленні Ірини Жиленко постає як корелят душевного стану. Авторка підкреслює, що істинність прояву душі є міра наближення іiі до Бога. Стилістичний ефект досягається ампліфікацією порівняльних конструкцій: $\epsilon$ душі, як 
літо, як соло / Застиглі самі серед себе... / Їх голос - як гомін сосон, / Настроєних на рівновагу / Щасливим самогіпнозом... / О, бути для себе магом, / І Богом, і вищим смислом / Життя! (5, с. 24).

Металогічний образ літо авторка розуміє крізь символ печалі як узагальнений образ вічності, тривалості, постійності, невідворотність прощання й починання чогось, усвідомлення безперевності зміни ночідня; весни-літа; осені-зими; народження-смерті: Поле прохололо. / I пахне житом, рідно, старожитньо, / I в запах той мішається чебрецьь. / I, щуоб печаллю душу освіжити, / Встає над полем синій туманецьь... (5, с. 290). Філософічність осмислення літнього вечора розкриває через образи людського і природного, які на перший погляд неспівмірні, але насправді перебувають у тісних взаємозв'язках як складники вічності: Такі иее неспівмірні величини: / Дитя і небо, хлопчик $i$ земля! / Біжить синок в червоній сорочині, / Мені вечірнє небо прихиля (5, с. 291).

Авторка подає розуміння неспівмірності шляхом уведення зіставних рядів. Сюжетна лінія розгортається протиставленням життя (духовного поступу) і смерті (занепаду): І розчиняє - за дверима двері - / У дні щзораз дивнішої краси. / Мчить завойовник часових імперій... / І далину, і глибину, і простір - / Об'ємлю все. Я вхожа. Я своя. / Бо мій малий синок, з лелеку зростом, / Притримав небо, щяоб змогла $і$ я / Ввійти за ним... / 3 веселими і добрими очима / Туди, де смерть уже не має прав (5, с. 291).

Образ літа у світоглядній картині авторки подається у вигляді монологічного роздуму ліричної героїні, коли нанизування однорідних рядів, в яких змістовно відтворено дії, об'єкти спостереження, створюють стилістичний ефект невпинного пошуку життєвого смислу. Зауважимо, що від пізнання глибини світу в досвіді авторки залишається певний біль і безпричинна радість: Бо знала я, щзо всі иляхи / Людські зіходяться в людині. / Гукай до неба, до птахів, / До зір, до лісу, до пустині, / Волай хоч до самого Бога, - / Ніде нікого і нічого... / I з нею (людиною) - трави, зливи, птиці, / I стільки смислу і краси - / Аж біль, аж уночі не спиться, / І уві сні сміється син (5, с. 294). 
Опис діалектичності буття лірична героїня подає шляхом паралельного використання прямого і переносного значень слів: Дош лив... Срібліли вівсюги. / Дзвеніло моє тихе щзастя. / Дзвеніли голуби з фольги, / $A$ їм відлунювали айстри... (5, с. 294). Лірична героїня відтворює при описі картини літнього явища полідинамічність навколишнього світу, коли одночасно дія відтворюється різними об’єктами і з різною метою, оскільки для кожного із них буття має свій рівень смилотворення. 3 метою досягнення художньої мети використано складнопідрядні речення з підрядними причини: Стояла ніч великих злив, / Як срібно-кришталевий палач. / Гриби не спали, бо росли. / Дощзі не спали, бо ішли. / А я не спала, бо не спалось... (5, с. 294).

Осіння пора - пора року між літом і зимою, яка характеризується скороченням дня, поступовим похолоданням, відльотом птахів у вирій, скиданням рослинами листяного покриву [2, с. 859]. Символіка осені в українській лінгвокультурі пов'язана 3 образом матерi [4, с. 423]. Світоглядно в поетичному мовленні Ірини Жиленко осінь постає традиційно як період у житті людини, коли вона відчуває себе найбільш щасливою. Для ліричної героїні, безперечно, це пора дитинства: Звучала осінь. Радісно. Отак / Дитинство нам звучить, зітерши втому.. / ... Стояла тиха осінь на землі... (5, с. 48).

Ми підкреслювали, що наскрізно світоглядну позицію ліричної героїні пронизує печаль, смуток від розуміння плинності й одночасно вічної таємності, невловимої непізнаності всесвіту. Оригінальним є втілення образу печального світу: Вітрецю хитнув прозорих тіней сітку. / А павучок щуось плів собі і плів. / І в затінку оранжевої квітки / Під вечір посмутнішало бджолі. / Стояла тиха осінь на землі...(5, с. 49).

Останні два рядки дають змогу достатньо прозоро декодувати значення простору, охопленого осінньою порою - уся земля. Осінньої пори, на переконання ліричної героїні, почуття спільні, відчуттні для кожної частинки всесвіту.

Лірична героїня образ осені порівнює із часом, коли душа засмислюється про плинність цього світу, про те, що насправді 
істинно живою є душа - душа ц̧вітіння. Думку авторка втілює шляхом протиставлення в поетичних рядках ключових слів життя / смерть; запустіння / ивітіння; земне / божественнее; душа / земне / Бог: Відквітнув квіт життя. Осінне запустіння. / Лишилася сама душа цввітіння. / Усе земне, щзо має квіт і плід, Чия хода іщуе лишає слід. / Життя вже не стосується мене... / Мене нема. Лишилася душа... / Кому вона потрібна, окрім Бога? / А отже, - Бог із нею, Бог із нею... $(5$, c. 461$)$.

Осінь набирає значення сакральності 3 позиції намагання людини осінньої пори (на схилі смеркаючих літ) осмислити задум Творця одночасного життя і вмирання всесвіту. Оригінально роздуми про життя осінньої пори подаються у формі діалогу з Богом, який витлумачує сенс існування всесвіту. Репліки містять відповідно ряди із протиставленнями: плоть / душа; ніч / день; смерть / безсмертя. Стан душі описується шляхом використання лексем на позначення деструктивних відчуттів: страх, холод, самотньо, голо, безсоння, смеркаючи літа. Звертання до Бога відтворюється шляхом нанизування риторичних питань, що підкреслює значущість питань для осмислення сенсу людського поступу: Я поскаржусь в отвіт: / «Непривітен иеей світ... / В пізню осінь / На схилі смеркаючих літ... / Кожна гілочка в ньому ночами дрижить. / Звідки знать тобі, Боже, про страх і холод? / Звідки знать тобі, Боже, як страшно жить, / Як самотньо і голо?... / Що ти знаєш про те, як густіє тінь?» (5, с. 336).

Поетичні рядки репрезентують осмислення життєвої путі і путі Божественної шляхом протиставлення безсоння малого (людського) $i$ великого (божественного). Безкінечність у розумінні людини і Бога має різні значення, що знайшло відображення у зіставленні також земного і вічного (безкінечного, небесного): I не спиться мені - поки гухають сови, / Поки дощ, безкінечний ллє. / Що ж, у Господа Бога своє безсоння, / а у мене безсоння своє. / То не дощ бубонить $і$ не гухають сови, / То під скорбне мовчання ялин / Розмовляють безсоння з безсонням, / Величезне безсоння - з малим (5, с. 336). 
Грунтовний аналіз образів пір року в художньому мовленні Ірини Жиленко дозволяє дійти висновку про те, що пори року співвідносні із душевним поступом, внутрішнім станом людини. Пори року допомагають осмислити вічний перебіг часопростору Всесвіту, віднайти смисл життєвої путі людини, гармонію 3 навколишнім світом, оскільки перманентною ознакою всесвіту є взаєморозуміння, невпинний діалог.

Художня творчість Ірини Жиленко позначена змалюванням синестезійних образів пір року в художньо-мовленнєвій організації поезій. Авторка ототожнює із весною і літом захоплений стан любові. Виявляємо ключові компоненти «юність», «золотий», «пожежа», «бузок», «гарячість», «легкість», «крилатість», «квіт», «ясність», що дає підстави зробити висновок про те, що для ліричної героїні весна і любов уподібнюються на основі сяяння, глибини рухів, розквіту, оновлення, злету: [Була весна]. Я привела його у дім... / I світив мені він так, / Аж думали сусіди, щуо пожежа. / А я ставала юно-золота, / Осяяна, легка і безтурботна... / Була весна. Цвіли ясні бузки. / Надходило парке, гаряче літо. / I Місяц̧ь и̧вів, крилатий і легкий, / Довкола нього квітували діти (5, с. 234).

Поетичний простір Ірини Жиленко представляє також образ ліричної героїні, яка переосмислює світоглядні позиції, спостерігаючи над плином зовнішнього світу i вічністю внутрішнього, що виявляється у представленні в художньо-мовленнєвій організації неперервної зміни пір року, розкриття їх найбільш визначальних, перманентних ознак, властивостей, які, на думку ліричної героїні, спонукають до переосмислення дійсності: зима - Різдво, позолочені сльози - сніг; весна - гілочка мімози - блакитні сльози - квіт спокус; осінь - осінній бруд, страшна істина, всесвітній $і$ несхибний дош (сльози вічності; невідворотність долі); квіт ілюзій: Осінь залягла одразу по весні. / Темна, сіра, безнадійна осінь. / Я чекала, щзо врятує сніг, / Що Різдво нам позолотить сльози. / Я чекала од весни спокус: / Відживи - хоч гілкою мімози! / Дай всміхнутись хоч куточком вуст / 
(найгіркішим) крізь блакитні сльози. / Час зими пройшов і проминув. / Час весни бреде осіннім брудом. / Прозріваю істину страшну: / ...осінь, дош - всесвітній і несхибний. / Мертві хризантеми у вікні... / I безшумно з неї (Землі) обліта / Квіт ілюзій... (5, с. 326).

Своєрідно в поетичних рядках спостерігаємо послідовність змін пір року: Осінь залягла одразу по весні. Висновуємо, що для ліричної героїні пора року символізує певну усвідомлену істину про щось. Актуалізація цієї істини зумовлює внутрішній стан людини відповідно до цієї пору року: Час весни бреде осіннім брудом.

Для ідіостилю Ірини Жиленко характерне медитативне пізнання пір року. Яскравим прикладом цього є цикл «Літо з осіннім поглядом», у якому спостерігаємо своєрідність літньо-осінньої пори, яка бачиться ліричною героїнею крізь метелика на руиі; золотий дощик; день айстр; рожеве вечірнє поле; вечір зі срібною голубкою; ніч великих злив.

Спостережувані явища спонукають до філософського сприйняття навколишнього світу, розуміння його краси, гармонії, простоти i складності водночас, світу, який може одночасно містити і виявляти різні його складові (у руслі нашого спостереження - перманентні риси i стани пір року; одночасне емоційне сприйняття пір року відповідно до світоглядних позицій): Сіє дощик. Сіруватенький. Простий / (ох, пробачте, - не простий, а золотий). / Передосінь. Жовті квіти. Світлий сад. / Це щуоб легше озирнутися назад - / В юне літечко, $i$ далі - y весну... / А метелик, величезний $і$ квітчастий, / Сів на руку $i$ довірливо заснув. / Не злякать би, / Не здмухнути цуього щзастя! (5, с. 281).

У наведеному уривку спостерігаємо ключові образи: передосінній дощчик $i$ квітчастий метелик. Кольоровий фон дозволяє створити атмосферу радісного підйому, коли відчуваєш щастя від того, що живеш і спостерігаєш прекрасні явища в цю передосінню мить. Задля цього уводиться протиставна конструкція (дощикк не простий, a золотий), що доводить нашу позицію про те, що погляд на навколишню дійсність залежить від напряму (конструктивного чи деструктивного) іiі естетичного споглядання. Уміння сприймати красу навколишнього 
світу узагальнюється ліричною героїнею як стан справжнього, істинного щастя (не злякать би, не здмухнути цьього щуастя!).

Ірина Жиленко розгортає дискурс осінньої весни в контексті переосмислення життєвого шляху. На думку поетки, людина весняніє, допоки вміє зберегти в душі весну, тобто мрійливість, щ̧ирість, чистоту устремлінь. Лірична героїня стверджує, що восени квітнуча квітка приносить весну, як мрії у час старості - життя. Висновки авторка подає через парцельовані складнопідрядні речення iз причинно-наслідковими відношеннями: B тихих садах не мина / Тиха осіння весна... / Квітка одненьким-одна. / Квітне - а отже, - весна. / Мріє людина стара. / Мріє. Тому й не вмира (5, с. 445).

Отже, важливими засобами творення образів пір року, загострення сюжетних ліній і надання яскравої експресії твору, а, найголовніше, створення часопросторового ефекту у творчості Ірини Жиленко, є система образів пір року й образу людини, а також мовні прийоми, що реалізують художню мету відтворити взаємозв'язок навколишнього світу й людини, надаючи виразності, влучності, емоційності поетичній тканині. Синестезія образів пір року дозволяє подавати характеристику порам року з позиції досвіду життєвого шляху. Окрім того, спостерігаємо багатозначність образів пір року: осіння весна, літо з осіннім поглядом, день айстр; рожеве вечірнє поле; вечір зі срібною голубкою; ніч великих злив.

Концепт «час» $є$ однією із основних категорій мовної картини світу і логічною частиною астральної моделі світу, оскільки саме рух небесних тіл небосхилом визначає астрономічне поняття часу. Основоположним для нашого дослідження є астрономічне сприйняття часу, яке грунтується на циклічності природних подій, що повторюються, - пір року, фаз місяця, доби та інших часових відрізків, i $\epsilon$ визначальним у створенні концептуальної моделі часу в українській мовній свідомості, що знайшла відображення в системі мови та іiі функціонуванні, а також в астральній моделі світу. Лінгвальне вираження концепту «час» у поезії Ірини Жиленко відбувається через 
реалізацію темпоральних значень, носіями яких у контексті є окремі лексичні одиниці. Перспективою подальших студій $є$ дослідження функціональних можливостей мовних одиниць на позначення корелятів земної моделі світу.

\section{Література}

1. Бондар О. І. Темпоральні відношення в сучасній українській літературній мові : [монографія] / О. І. Бондар. - Одеса : Астропринт, 1996. - 192 с.

2. Великий тлумачний словник сучасної української мови / уклад. і голов. ред. В. Т. Бусел. - Київ ; Ірпінь : ВТФ «Перун», 2007. - 1736 с.

3. Дударева 3. М. Время в концептуальной и языковой картинах мира / 3. М. Дударева // Вестник Урал. гос. тех. ун-та. Серия филологическая. Екатеринбург, 2005. - № 60 (8). - С. 110-118.

4. Жайворонок В. Знаки української етнокультури. Словник-довідник / В. Жайворонок. - К., 2006. - 704 с.

5. Жиленко І. В. Свангеліє від ластівки : вибрані твори / І.В.Жиленко ; передмова М. Жулинського. - К. : Пульсари, 2006. - 488 с.

6. Задорожна О. М. До історії вивчення концепту «час» у вітчизняному мовознавстві / О. М. Задорожна // Лінгвостилістика : зб. наук. праць. - К. : НАНУ Ін-Т укр. мови, 2007. - С. 176-179.

7. Тимофеев Л. И. Основы теории литературы / Л. И. Тимофеев. - М., 1976. - 234 с. Стаття надійшла до редакиіï 11.06.2016 p. 